\title{
Grigor Narekatsi in the Scope of Levon Shant's Scientific Interests
}

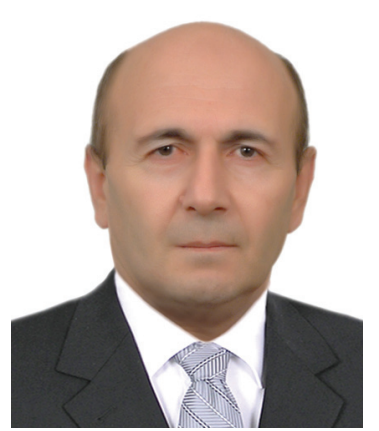

Sargis Mkhitarian

Great is the service of Nikol Aghbalian and Levon

J Shant in the noble cause of investigating and systematizing old and medieval Armenian literature. During his lectures N.Aghbalyan studied and circulated a great number of manuscripts and colophons to meet the demands of his listeners interested in medieval Armenian literature (Aghbalian 1970:9-12). Meantime, after finishing his studies in Germany, L.Shant returned home. Most probably influenced by aesthetic and philosophical theories of Schopenhauer and Nietzsche and traditions of romanticism Shant created his two famous works - "Ancient Gods" and "The Chained" which became reflections of Armenian Renaissance conjoined with the abundant West Armenian pagan tendencies of early $20^{\text {th }}$ century. But the range of professional interests of the artist was beyond these issues. In complex political contexts he touched upon such topics concerning Cilician Armenian medieval developments as Armenia-Byzantine knotty and intricate relations. The historical dramas "The Princess of the Fallen Castle", "The Emperor", "Oshin Payl" refer to this period. The works raised a number of pressing questions and testify to Shant's great command of the time (Shant 1946:198).

Written in 1943-1946 Shant's “A Glimpse of Armenian Folklore” (Shant 1946:464) is a versatile and profound study of rather the history of Armenian literature than the study of Armenian folklore. The author states that the history of twenty-seven centuries of Armenian survival may be divided into seven main periods. The fourth epoch (mid $7^{\text {th }}$ $11^{\text {th }}$ centuries) is characterized by the Arab domination and "the rule of a new religion, persecutions and violence" which originated in the South. It was also the period when some noble families (the Bagratids and the Ardzrunis) managed to set up kingdoms which "had to struggle both against the constantly renewed religious demands and political claims of the Byzantine empire" (Shant 1946:12-13).

This was the very period when the medieval genius Saint Grigor Narekatsi (950-1003 AD) created his masterpieces. According to V.Oshakan "From greatest conquerors to humblest tyrants in the East revered this wise man [Narekatsi] and didn't dare to revile his interference" (Oshakan 1942:34). It is on Christian ideology that the great hermit Narekatsi built the edifice of his thoughts and feelings. It is on Christianity that Shant expresses the following opinion, "Even after becoming gentle and noble, being a kind captain, a provident, merciful and kind father - did the Christian-propagated monotheism remain to be complex, difficult, continuously dispute-provoking. Unity and Holy Trinity, human and God - to these are the idea of birth, the image of human indisposition, tortuous explanations, doctrines and sectarianism related" (Shant 1946:110). Then Shant comes to a most important conclusion: "The great value of Christianity lies in its 
requirement for human psychological evolution and a still higher social collectivism and organization. It propagates altruism versus the radically narrow-minded selfishness of the prehistoric man.... On the other hand, looking down upon secular values and wealth and striving for spiritual and divine heights it will enhance human inner dignity and pride" (Shant 1946:110).

Such an evaluation reveals the essence of a religion which is daring and autocratic and advocates egalitarianism. And it is the human striving for eternity, as well as the idea of being God's exceptional minion that induce humans to protest. In the following way Shant formulates the human exalting idea that he will belong to heaven if his wearied soul strives for it: "He wants to be a truly divine being but on earth, he wants to be like his Christ who was God in human body" (Shant 1946:111).

Interestingly enough Shant considers that the public "ideal" is something unreal, something that exists "only in books and on paper" (111). The powerlessness of man contradicts to the cherished desire to achieve his ideals. "The antagonism between this indefeasible reality and the abstract striving of the human soul gives birth to an unimaginably sweeping trauma for the truly Christian souls" (111).

Such emotions were typical of almost all great figures. For example Grigor Narekatsi is a classical example of "exactly that kind" of religious fathers who "lived and created in a small monastery situated in front of Lake Van under the protection of his cleric relative Anania Narekatsi" (112).

The poet Narekatsi led a solitary and contemplative life. He read a lot to fill up his religious knowledge. According to Shant "He is a talented person endowed with subtle senses, deep feelings and a lively speech" (112). His poems are religious songs but "very often they go beyond such limits and turn into images of reality or fine exuberant descriptions of nature" (112). Such poems as "The Small Cart" and "Vardavar" would be enough to consider Narekatsi an author with a great sense of taste and individuality, "the best among many"(112).

Shant considers "The Book of Lamentations" the most significant one among Narekatsi's works. All of a sudden "the strivings and sufferings of the Christian hermit encircled in subtle and deep wisdom flow out, he feels the skyward flight of his soul and will, he proudly determines to reveal subtleties and greatnesses, things that exceptional individuals are required to do"(112). M.Mkryan points out the great aesthetic value of Narekatsi's songs considering them wonderful descriptions of the $10^{\text {th }}$ century reality, nature and humanity (Mkryan 1976:474-477).

It is first and foremost the specific form of Narekatsi's masterpiece that attracts Shant's attention. On the one hand the poet is a human being, a mortal; a fact that he isn't able to conciliate with and constantly focuses on. On the other hand we face "the inaccessible height and the almighty power" of the writer (Shant 1946:113). Although the series of his prayers is also called "Narek" or "Book of Prayers", in fact "they are prayers neither in essence, nor in form and spirit.... "Narek" presents the deep agitation of the human soul..., the striving and soaring of the waters to the sky" (Shant 1946:113). Beyond the form there lies another world, the mysterious and imaginative otherworld which is verbally difficult to describe. 
And here are lines formulating the essence of the poem: "A genuine work of art is the true reflection of spiritual emotion" (Shant 1946:113). As to the clarification of the aesthetic interpretation of the work, Shant claims that faithfulness towards spiritual imagery is the basis of the aesthetical. The greater the reflection of public emotion is, the bigger admiration and interest towards a works of art will be. "Narek" is an exclusive work of art, simple, yet deep and spontaneous. It is not only the most mysterious and valuable expression of medieval Armenian Christian literature but is also "a unique and strong belch of universal Christian spirituality"(114). It is worth mentioning that the above evaluation of the now world famous "The Book of Lamentations" is not only truthful but is also precise, especially at a time when the book was not so famous in the world.

Shant has come to a surprising conclusion as to the type of Narekatsi's poetry. In addition to considering Narekatsi a Christian poet because he is an adherent of Christian faith, a bearer of Christian mindset and education, Shant thinks that the poet "has pagan inclinations and a pagan talent" (114). Probably this was the way paganism found an outward expression in the poet's time. And this was because Early Christian thought itself was greatly influenced by Egyptian theology (Manandyan 1956:287-322). What we think at this point is that pagan thinking is incoherent, in some sense incompatible with Narekatsi's essence. He may be willing to reestablish some pagan traditions but cannot be regarded as pagan himself.

A very strange approach to Armenian history and literature emerged in the late $19^{\text {th }}$ century and predominated over the whole of the $20^{\text {th }}$ century. The approach was based on academically groundless and incorrect opinion that Armenian historiographers and writers falsified both history and literature. This viewpoint, reconsidering many traditional approaches, misrepresented and distorted knowledge of our historiography and literature. Since the $70-90$-ies $\left(19^{\text {th }} \mathrm{c}\right.$.) western scientists have drawn a groundless conclusion that M. Khorenatsi, Eghishe and other Armenian historiographers presented false versions of our history (Abeghyan 1968:282-283). On this very basis and under its influence Shant and some diaspora armenologists claimed that "Christianity dislikes individuality, it likes the ecumenic" (Shant 1946:115). Then he concludes: "Christian prayers and psalms don't accept the 'self', the vast majority of them points to plurality - 'we', 'our', etc." (115) Likewise, the $20^{\text {th }}$ century distinguished armenologist R.Thomson states that Armenian historiographers distort the reality and Armenian poets are deprived of their own self. The same opinion concerning Narekatsi is expressed by Anne and Jean-Pierre Mahes. The opposite opinion is expressed by Armenian historian H.Mirzoyan who states:

1."The Book" is not simply a prayer book. It is "The Book of Lamentations". It is how the author called it considering its generic peculiarities."

2. "It's at least strange that on the one hand researchers of Narekatsi claim that "The Book" is an exclusive species of world and Armenian literature, on the other hand they state that it lacks the author's biographical data and his self is not expressed in the book (Mirzoyan 2004:71-81; 2008:6-7).

According to Shant God is the "self" while "all the believers together are a single whole before the God" (Shant 1946:115). Fortunately he realizes the incorrectness of this point at least towards Narekatsi and states: "Narekatsi is alone in his prayers, as a per- 
son, as an individual who speaks to Christ about himself and his soul without focusing on others" (Shant 1946:115). This results in personal sufferings, psychological drama, struggle between the divine and human beings and the human finds his way out of the collective submissive state. A global cataclysm takes place. "In the songs [Narekatsi's] and in the prayers" is the poet's proud spirit that struggles against the pressure of the Almighty claiming his human rights and questing for freedom of his being. "When going deep into Narek's poetry we see that it is not a bewail, it's rather a protest..., it's not downfall, it's rather the flight of a powerful human spirit to the sky.... It will be strange to look upon those songs and speculations as simple prayers of a Christian believer" (116). This means Narekatsi's poems are not simply prayers, but deeply individualized lyrics where the ego of the hero is entirely accentuated. Not to be mistaken, he formulates his speech to God on behalf of his own "self" and to prove the truth, veracity and frankness of his words and person he confirms the main ideas with "Amen".

Such a great conflict between the human and the divine "resembles the pagan image of the struggle between Prometheus and Zeus" (117). Shant considers "The Book" a strange prayer in the sense that it is not quite natural for the author to ask Almighty to live within his physical being. A thing that is impossible. "What a prayer it is if you are turning to your beloved and professed God and saying ... 'You have kept all the matters of honour and high positions for yourself and have placed the bad and heavy burdens on my shoulders'... This is no prayer and glorification, this is a struggle, a demand for human rights" (116). In this particular case the human revolts against God who cares for his own "self", not "for people". This point is very important not in the sense that worthy is the human inducement to protest (typical of Renaissance) but in the sense that what is revealed is God's "self love". And not only that. Why not God's rigor despite his being a source of boon. Perhaps it's a matter of speculation moved forward by the evil spirit, the one who accuses God of concealing boon from people. The medieval philosophers declare that there was no reason for God to hide the forbidden fruit from Adam as sooner or later he would learn the life-and-death truth himself. There was really no need to conceal anything from His beloved one - the first human. Narekatsi realizes that he is in struggle with God, yet knowing that he is the loser. Therefore, he acknowledges his defeat.

The essence of Narekatsi's preoccupation, according to Shant, is "his soul, his essence, his individuality, his present and future, and the mortal man" (117). Of course, this approach should not be misinterpreted as individualistic or egocentric. Vice versa, the poet is a selfless individual whose interests lie beyond the world of matter. He strives to find out (for himself and as a result for everybody else) whether a person can quest for salvation. It's very important for him to penetrate this divine mystery.

Shant considers that the poet's spiritual anxiety is caused by contradiction and uncertainty to find his way out. Narekatsi has problems "but no solutions to them as Christianity and paganism, individualism and collectivism, the hermit and the protestant, the saint and the sinful, Christ and Satan are all mixed up in his soul and he desperately tries to discern the destination of his shabby life cart. This is a human soul placed before us; naked but full of art"(120). 
It is for possessing a contradictory and sorrowful human soul that Shant regards Narekatsi as "the Bard of Christianity" and one of the greatest figures of Renaissance, thus rejecting the Armenian Diaspora approach that the notion of similarity between Narekatsi and the representatives of Italian Renaissance is put forward by armenologists of Soviet era (Pltyan 2001:31-32). It should be noted here that the Armenian Renaissance as part of globalization of world culture started in the late $10^{\text {th }}$ century (Mkhitaryan 2007:115)

The following well-aimed observation of Shant is also worth mentioning: "Narekatsi is great also because his soul darts out of Medieval Christianity into the tribulations of the new era" (Shant 1946:118).

One of the most important aspects of Narekatsi's poetry is the author's love and vivid depiction of nature. It symbolizes the poet's struggle for being and remaining humane. And finally Shant concludes: "Narekatsi's song-prayers, created many years before the Renaissance, sound like a longing for a new era, for human physical and spiritual freedom still to come, for the voice and spirit of the future Renaissance. And this is a testimony of a creative and profound Armenian spirit" (Shant 1946:120).

This estimation of Shant, a true researcher who graduated from several European universities, an erudite thinker and a talented scientist of Renaissance (Davtyan, Lalayan 1986:28) is not incidental. Shant is well aware of the great ideological and aesthetical value of the "The Book" and pays special attention to the significant poetic and spiritual achievements of Narekatsi. It is an undeniable fact that Shant is greatly interested not only in the medieval genius Narekatsi but also in issues concerning early Armenian Renaissance.

\section{References:}

1. Aghbalean, N. (1970) Patmutyun hay grakanutyan. Vol. 4. Peyrut: La-photo-bress Publishers.

2. Abeghian, M. (1968) Yerker. Yerevan: ASRA Publishers.

3. Davtian, H., Lalayan, E. (1986) Narekatsu ashkharhayatske. Yerevan: YSU Publishers.

4. Hayuni, M. (2001) Narekean voronumner. Beirut: Sipan Press.

5. Manandian, H. (1956) Hermeay yerametsi ar askghepios sahmank. // Banber Matenadarani. Vol.3. Yerevan.

6. Mkrian, M. (1976) Hay hin grakanutyan patmutyun $\left(5-10^{\text {th }} c c\right)$. Yerevan: YSU Publishers.

7. Mirzoyan, H. (2004) Aghotagirk te matyan voghbergutyan? // Grakan tert. N3, Yerevan.

8. Mirzoyan, H. (2008) Ardyok matyanum chka banasteghtsi yesy? // Grakan tert. N27, Yerevan.

9. Mkhitaryan, S. (2007) Ardi mijnadaragitutyuny yev haykakan veratsnutyan khndiry. // Patmabanasirakan Handes. Yerevan.

10. Oshakan, H. (1942) Aghachem zanpopokheli. N 1-2, Sion. 
11. Pltean, G. (2001) Gorts arkanel. Verstin Grigor Narekatsi. Montreal: H. A. Surb Hakob Mayr Yekeghetsi Press.

12. Shant, L. (1989) Yerker. Yerevan: Sovetakan grogh.

13. Shant, L. (1946) Endhanur aknarkner hay banasirutyan vray. Peyrut: Tparan hay tchemarani.

\section{Appqnp suptilughe}

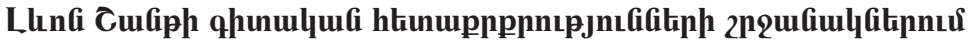

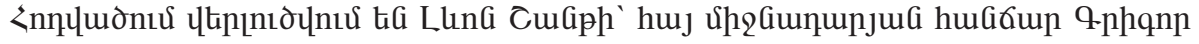

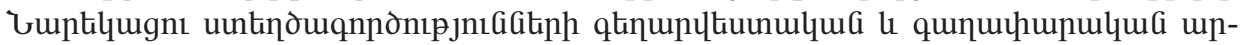

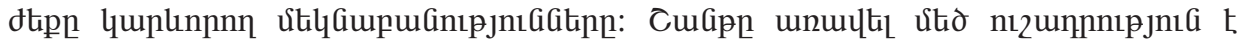

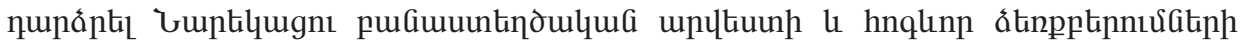

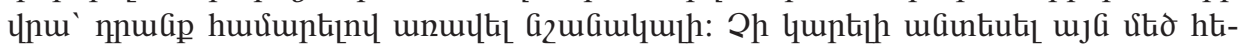

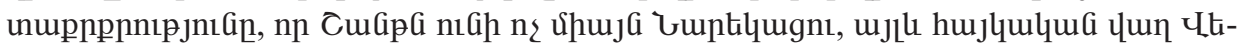

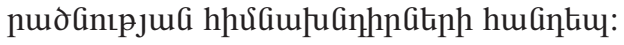

